\title{
Skeletal Metastasis in Carcinoma Penis Case Report with Review of Literature
}

\author{
Gaurav Sharma ${ }^{1}$, , Sweety Gupta ${ }^{1}$, Ajai S Krishnan ${ }^{1}$, Rachit Ahuja ${ }^{1}$, Meenakshi Sharma ${ }^{1}$, Michael Leonard \\ Anthony ${ }^{2}$, Biswajyoti Das ${ }^{1}$, Sanjay Sajeevan ${ }^{1}$, Lekshmi ${ }^{1}$, Vandna Dhingra ${ }^{3}$ and Manoj Gupta ${ }^{1}$
}

${ }^{1}$ Department of Radiation Oncology AIIMS Rishikesh, India

${ }^{2}$ Department of Pathology AIIMS Rishikesh, India

${ }^{3}$ Department of Nuclear Medicine Rishikesh, India

Submission: April 26, 2020; Published: May 07, 2020

*Corresponding author: Gaurav Sharma, Department of Radiation Oncology AIIMS Rishikesh, Uttarakhand India

Abstract

Bone metastases are rare in carcinoma penis mostly localized in the axial skeleton. We here present patient of carcinoma penis who progressed to multiple bony sites after surgery in short time interval within 6 months.

Keywords: Carcinoma penis; Bone metastasis; Palliation

\section{Introduction}

$1 \%$ of male cancers is constituted by penile cancers and most common histological type is squamous cell carcinoma in $95 \%$ cases $[1,2]$. It commonly occurs in $6^{\text {th }}$ decade. Carcinoma penis is usually a localized disease with metastases occurring in $<3-$ $5 \%$ of patients $[1,2]$. Inguinal nodes followed by iliac nodes are commonly involved. Most common sites for distal metastases are retroperitoneal lymph nodes but bone involvement is rare $[3,4]$. Occurrence of bone metastases is usually localized to axial skeleton. Reports of bone metastasis in appendicular skeletal regions from carcinoma penis has been are very few. In the present study we report case of patient with carcinoma penis presenting with appendicular bone metastases (sacral, ischial metastasis and tarsal region).

\section{Case Presentation}

48 years male who was previously diagnosed with carcinoma penis underwent partial penectomy. Post-operative histopathology reported well differentiated squamous cell carcinoma (Figure 1). Patient defaulted and presented to Radiation Oncology outpatient department with complaints of severe pain and swelling in right lower limb. On Clinical examination there was fungating inguinal node with satellite nodules in right inguinal region (Figures 2 \&
3), pain score (Numeric rating scale 8/10). He also had tenderness in right ankle region.

There were no signs of deep vein thrombosis. Patient underwent contrast enhanced computer tomography of abdomen and pelvis which reported left side pleural effusion and mass lesion $5.4 \mathrm{~cm}$ in right side pelvic region.

Whole body Radionuclide bone scan was done suggestive of osteoblastic lesion in right superior and inferior pubic rami, bilateral sacral ala, and Right tarsal bone (Figure 4). In view of poor performance status, patient was considered for palliative radiotherapy to metastatic bone lesions and supportive care.

\section{Discussion}

Most common histology in carcinoma penis is squamous cell carcinoma other rare malignant lesions are basal cell carcinoma, Malignant melanoma, Sarcoma, M. Paget, Lymphoreticular tumours and metastases. Risk factors include low standards of hygiene, phimosis, recurrent balanitis, high number of sexual partners (early age at first sexual intercourse), presence of HPV infection, circumcision practice, strong tobacco consumption, genital ultraviolet radiation, and penile trauma. Inguinal lymph node involvement occurs early in penile carcinoma. The 


\section{Cancer Therapy \& Oncology International Journal}

metastatic potential is largely dependent upon the initial tumor [3]. Bone metastases has been reported in spine [4], femur [5], ischium [6] in previous case reports. In cases of metastases in the axial skeleton, surgical assessment is best option in case of spinal cord compression. Radiotherapy along with steroids is an option for palliation of symptoms. In patients with appendicular skeleton risk of fracture is high. Chemotherapy alone in metastatic disease is not curative. Response rates are low $(\leq 50 \%)$. Hypercalcemia has also been observed in osteolytic bone metastases $[7,8]$. Therefore patients with pain in carcinoma penis should be investigated to rule out bone metastases.
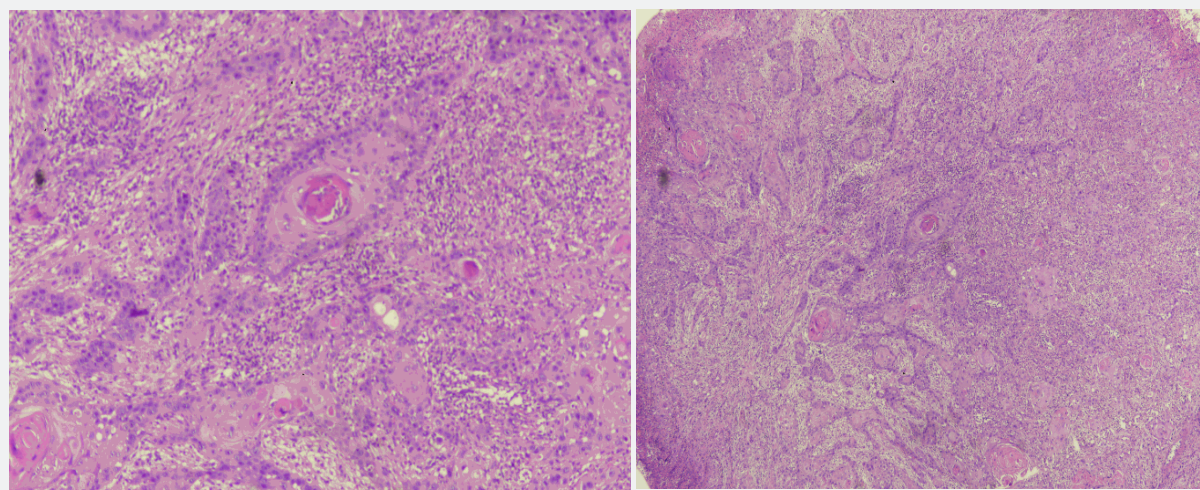

Figure 1a \& 1b: Microscopic photograph of histopathology of carcinoma penis (Well differentiated squamous cell carcinoma) showing keratin pearls.

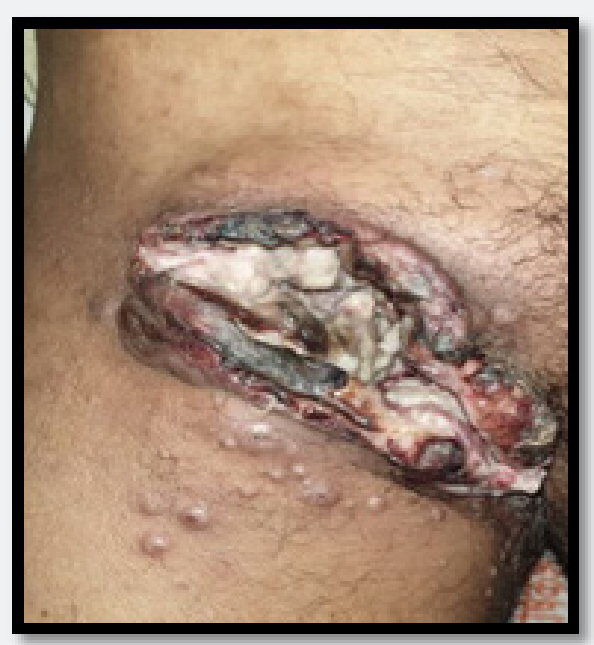

Figure 2: Fungating Lesion in Right Inguinal Region.

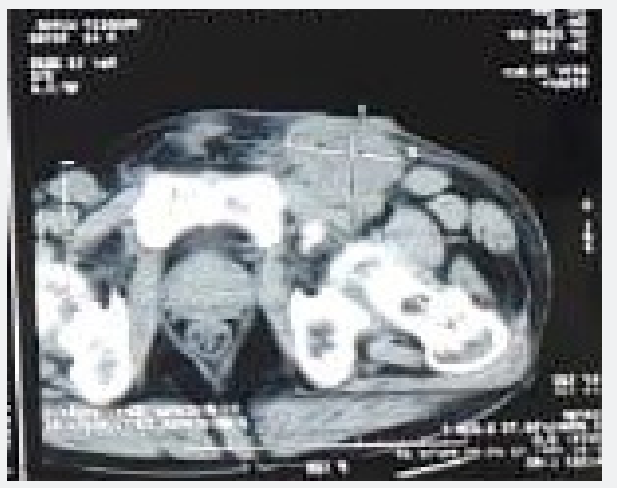

Figure 3: Contrast Enhanced computed tomography showing mass lesion $5.4 \mathrm{~cm}$ in right side pelvic region. 


\section{Cancer Therapy \& Oncology International Journal}

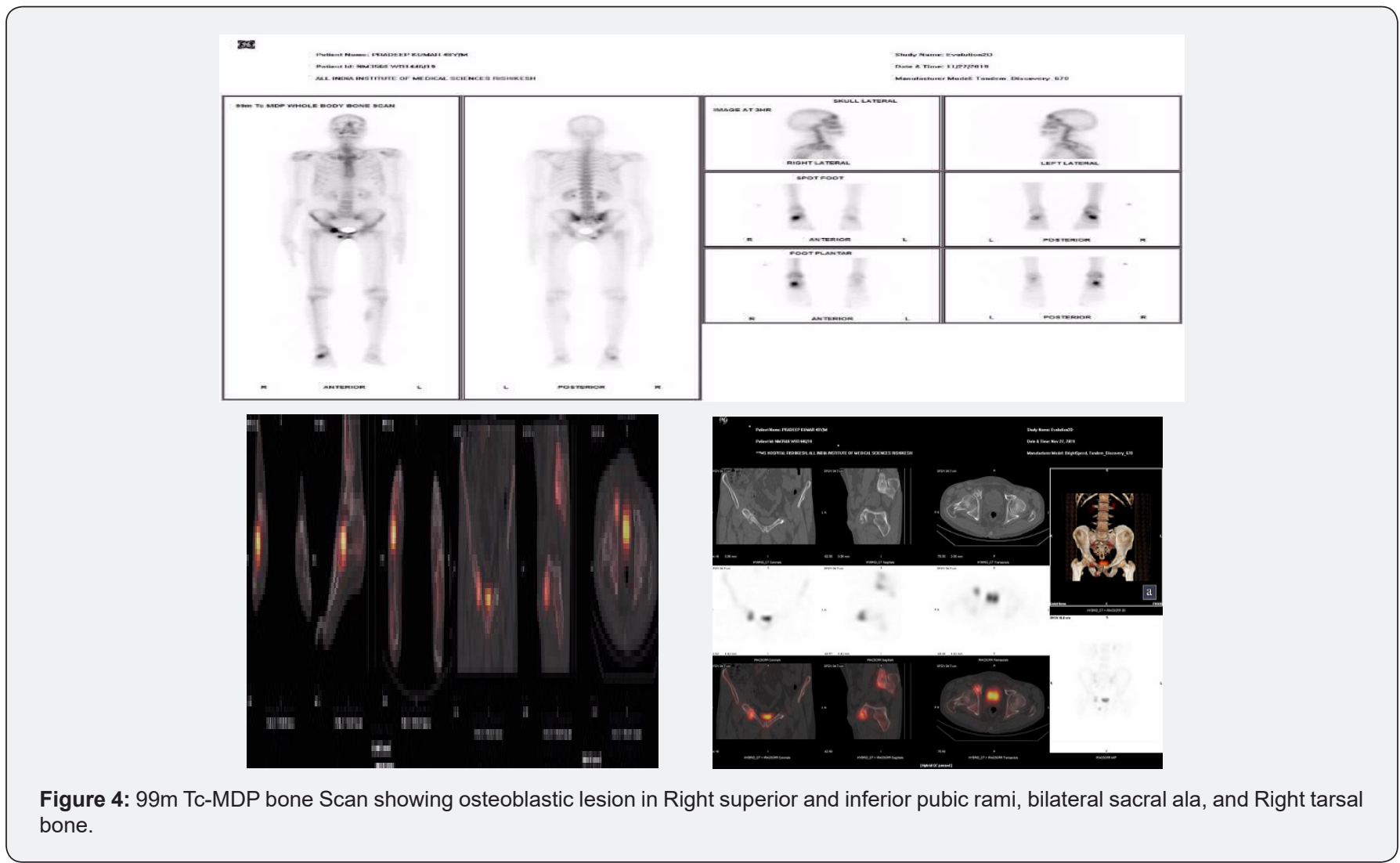

\section{Conclusion}

In patients with penile cancer with huge nodal burden at presentation is alarming sign during follow up metastatic work up should be done thoroughly to rule out metastatic disease.

\section{References}

1. J E Heinlen, D D Buethe, D J Culkin (2012) Advanced penile Cancer: International Urology and Nephrology 44(1): 139-148.

2. Barski D, Georgas E, Gerullis H, Ecke T (2014) Metastatic penile carcinoma - an update on the current diagnosis and Treatment options. Cent European J Urol 67(2): 126-132.

3. Lal P, Halder S, Datta NR (1999) Carcinoma of the penis metastasizing to the dorsal spine. A case report. Urol Int 62(4): 249-251.
4. R Jacob, R Jyothirmayi, A Kumar, MK Nair, B Rajan (1995) Case report: spinal metastasis from carcinoma of the penis. Br J Radiol 68(816): $1367-1368$.

5. A Lopez-Sastre Nunez, D Menendez Diaz, F Garcia, L A Perez (2000) Epidermoid carcinoma of the penis with vertebral metastasis treated with decompression and anterior fixation. Arch Esp Urol 53(7): 652654.

6. R I Gunko, SD Fomin (1989) Metastasis of penile cancer to the ischial bone. Meditsinskaia Radiologiia 34(1): 75

7. Ho CC, Nazri J, Zulkifli MZ, Sritharan S, Hayati AR (2006) Metastatic penile cancer presenting as hypercalcemia and pathological fracture of the humerus: a rare event. Med J Malaysia 61(4): 503-505.

8. Ayyathurai R, Webb DB, Rowland S, Stephenson TP, Thomas AJ (2007) Humoral hypercalcemia of penile carcinoma. Urology 69(1): 184.e9184.e10.

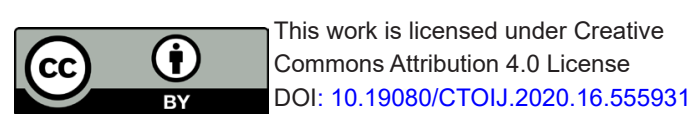

\begin{tabular}{|l|}
\hline Your next submission with Juniper Publishers \\
will reach you the below assets \\
- Quality Editorial service \\
- Swift Peer Review \\
- Reprints availability \\
- E-prints Service \\
- Manuscript Podcast for convenient understanding \\
- Global attainment for your research \\
- Manuscript accessibility in different formats \\
( Pdf, E-pub, Full Text, Audio) \\
- Unceasing customer service \\
Track the below URL for one-step submission \\
https://juniperpublishers.com/online-submission.php \\
\hline
\end{tabular}

